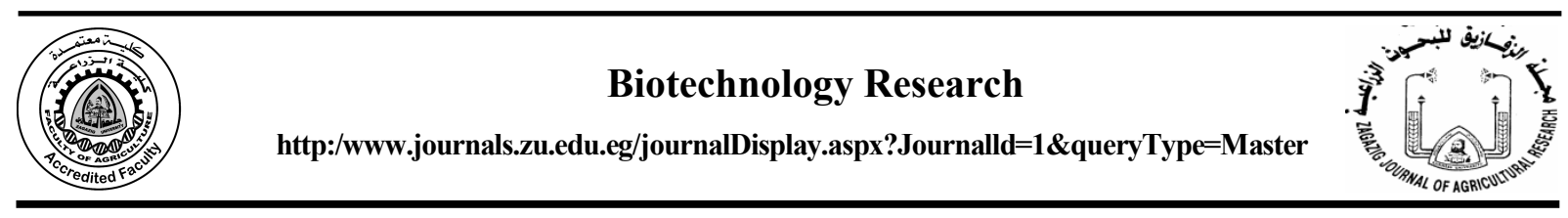

\title{
ISOLATION AND IDENTIFICATION OF EGYPTIAN STRAINS OF Serratia marcescens PRODUCING ANTIBACTERIAL AND ANTIOXIDANT PRODIGIOSIN PIGMENT
}

\author{
Mohamed A. Othman ", Fatma I. El-Zamik, M.I. Hegazy and A.S.A. Salama \\ Agric. Microbiol. Dept., Fac. Agric., Zagazig Univ., Egypt
}

Received: 17/07/2019 ; Accepted: 04/08/2019

\begin{abstract}
Prodigiosin is a natural red pigment, it is an alkaloid secondary metabolite with a unique tripyrrole structure produced by Serratia marcescens, it's motile, short-rod shaped, $\mathrm{G}^{-}$bacteria, classified in the large family of Enterobacteriaceae. 13 isolates were isolated from 32 soil samples, which showed clear red pigmented colonies. The Egyptian Serratia marcescens isolates were identified based on morphological, biochemical and then only the two best isolates for pigment production (M1, S1) were identified by MALDI-TOF mass spectrometry technique. The two selected species gave a score value between 2.565 to $2.668(100 \%)$ were correctly identified by MALDI-TOF- MS to the genus and species levels. The average daily rate of pigment production by M1 and S1 isolates estimated by 421.6 and 326.1 unit/cell, respectively. Antibacterial activity of prodigiosin was determined by disc diffusion assay against 7 types of $\mathrm{G}^{-}$and 4 types of $\mathrm{G}^{+}$pathogenic bacteria. Minimum inhibitory concentration (MIC) and the concentration inducing 50\% inhibition of the bacterial growth $\left(\mathrm{IC}_{50}\right)$ against the mentioned bacteria were determined and prodigiosin was proved to be effective in inhibiting bacterial growth. Prodigiosin possess antioxidant activity assayed by 2,2diphenyl-1-picrylhydrazyl (DPPH) reduction method and this activity increased gradually with increasing concentrations.
\end{abstract}

Key words: Serratia marcescens, MALDI-TOF-MS, prodigiosin, antibacterial activity, antioxidant activity.

\section{INTRODUCTION}

Serratia marcescens bacteria is $\mathrm{G}^{-}$bacilli belonging to the family Enterobacteriaceae, which are opportunistic to human, plant and insect. There are two types of Serratia marcescens; pigmented (red) and non-pigmented (white) strains (Hardjito et al., 2002).

Matrix-assisted laser desorption/ionization time of-flight mass spectrometry technique (MALDI-TOF MS) has been attracting attention as a tool for the automated identification of microorganisms. This device can identify microorganisms from prepared samples in about $10 \mathrm{~min}$, and the obtained results show a high rate of concordance with 16S rRNA gene identification. The efficiency, rapidity, and cost- benefit of this technique for the identification of pathogenic bacteria are well documented (Bizzini et al., 2011; Tadros and Petrich, 2013; Yonetani et al., 2016).

The production of prodigiosin by $S$. marcescens is influenced by numerous factors including inorganic phosphate availability, medium composition, temperature, $\mathrm{pH}$, and natural components in the media (Iranshahi et al., 2004 and Wei et al., 2005). Prodigiosin is a red pigment produced as a secondary metabolite by Serratia marcescens, Pseudomonas magneslorubra and Vibrio psychroerythrous etc. characterized with unique tripyrrole structure which is regarded as responsible for its reported pharmacological characteristics as anticancer, antimicrobial, antioxidant and immunosuppressant agents

\footnotetext{
*Corresponding author: Tel. : +201271572104

E-mail address: ma.ade192@gmail.com
} 
(Araújo et al., 2010; Samrot et al., 2011) and its unique characteristics as a natural based pigment for olefins and textiles (Gulani et al., 2012). The effective clinical properties of prodigiosin imply it as antitumor (Alihosseini $\boldsymbol{e t}$ al., 2008), immunosuppressive (Songia et al., 1997), phytopathogenic fungal inhibitor agents (Someya et al., 2003).

The purified pigment extracted from the biomass of bacteria was analyzed by mass spectrophotometry and showed the expected molecular weight of 324 Da corresponding to prodigiosin (Araújo et al., 2010). The large scale production of prodigiosin was achieved by using optimized growth conditions (time of incubation, temperature of incubation, $\mathrm{pH}$ of the medium, speed of agitation, carbon and nitrogen source used etc. (Phatake and Dharmadhikari, 2016).

The major advantage of pigment production from microorganisms includes easy doubling time, specific growth rate, fast in the cheap culture medium, and optimal environmental parameters (Su et al., 2011). The standardization of culture medium and fermentation conditions plays a very crucial role in the maximum production of prodigiosin (Su et al., 2011).

The aim of the present study was to isolate indigenous strains of Serratia marcescens and identify them using MALDI-TOF MS, and extracts the red pigment from culturable bacteria to evaluate its antibacterial activity against a series of bacteria and antioxidant activities.

\section{MATERIALS AND METHODS}

This study was carried out at the laboratories of Agric. Microbiology Dept., Faculty of Agriculture, Zagazig University, Egypt, during the period of 2017 to 2019 , in order to select efficient indigenous isolates of Serratia marcescens to produce a red pigment (prodigiosin). Thirty two moistured soil samples were collected from 8 locations from different districts at Sharkia Governorate. These districts namely Zagazig (Z), Belbais (B), Mashtool El-Sook (MS), Fakous (F), El-Hessenia (H), Menia El-Kamih (M), Abo Kabeer (AK) and Salhya (S). The aforementioned moisturized soil samples were used for isolation of different isolates of $S$. marcescens.

\section{Isolation and Purification of $S$. marcescens}

Pure cultures of $S$. marcescens isolated from soil samples, collected from aforementioned districts in Sharkia Governorate, were obtained according to Gulani et al. (2012). Each soil sample (10 g of soil) was transferred to sterile $250 \mathrm{ml}$ conical flasks containing $90 \mathrm{ml} 0.1 \%$ peptone water. Samples were serially diluted with peptone water up to $10^{-7}$ and plated on nutrient agar then incubated at $30^{\circ} \mathrm{C}$ for $2-3$ days. After incubation the plates were examined for red pigmented colonies and streaked on the same medium for purification. Pure colonies were subjected to slant agar and kept at $4^{\circ} \mathrm{C}$.

\section{Morphological and Biochemical Characteristics of $S$. marcescens}

The direct microscopic examination of stained smears of pure bacterial isolates was carried out for studying size, shape, Gram staining and hanging drop method which was used to study the motility of the bacterial cells. Biochemical and physiological testes of cultures were also examined according to (Grimont and Grimont, 2005) in the Bergey's Manual of Systematic Bacteriology $2^{\text {nd }}$ Ed., volume two, part $\mathrm{B}$ (the proteobacteria), the gammaproteobacteria.

\section{Identification of $S$. marcescens using MALDI - TOF - MS}

Identification of $S$. marcescens had been confirmed by using matrix-assisted laser desorption/ionization time of flight mass spectrometry (MALDI-TOF-MS) in peptide and protein analyses. One large colony from each of selected bacterial isolate (enough to fill about one half of a $10-\mu 1$ inoculating loop) was suspended in $70 \%$ ethanol in a $1.5 \mathrm{ml}$ microcentrifuge tube and loaded three times onto ground steel MALDI target according to the manufacturer's instruction (Bruker Daltonics, Breman, Germany). Matching between experimental MALDI-TOF-MS profiles obtained from bacterial isolates and the reference MALDI-TOF-MS profiles is expressed by a BioTyper according to a Log (score) and an associated-color code (green, yellow and red) was recorded. Micro Flex mass spectrometeries were performed at Academic Park, Faculty of Medicine, Alexandria University, Egypt, according to Biswass and Rolain (2013) and Nacef et al. (2016). 


\section{Presumptive Test for Prodigiosin Confirmation from $S$. marcescens}

The culture broth of selected $S$. marcescens (M1). was subjected to centrifugation process at $5000 \mathrm{xg}$ for $15 \mathrm{~min}$ and $10 \mathrm{ml}$ of $95 \%$ methanol was added to the cell pellet and centrifuged under the same conditions. Debris was removed and the $2 \mathrm{ml}$ of the supernatant was taken in two test tubes. The content of the test tube was acidified with a drop of concentrated $\mathrm{HCl}(30$ $34 \%$ ) and the other alkalinized with a drop of concentrated ammonia solution (30 - 32\%). A red or pink color in the acidified solution and a yellow or tan color in the alkaline solution indicated a positive, presumptive test for prodigiosin presence (Gerber and Lechevalier, 1976).

\section{Screening and Determination of Prodigiosin Produced by $\boldsymbol{S}$. marcescens Isolates}

Individual isolates of $S$. marcescens were transferred into $250 \mathrm{ml}$ conical flasks with 100 $\mathrm{ml}$ of nutrient broth medium (seed cultures are $10 \%$ of the total volume of the fermentation medium) and incubation at $30^{\circ} \mathrm{C}$. The prodigiosin was extracted, determined and the growth was followed by measuring the optical density (OD) at $620 \mathrm{~nm}$ after 48, 72 and $96 \mathrm{hr}$., of incubation.

\section{Quantitative Estimation of Prodigiosin}

The absorption pattern over various wavelengths was initially checked and it was found that the absorption maxima were at 499 $\mathrm{nm}$ where prodigiosin also absorbs maximally. At this wave length the absorptions were recorded on methanolic extract and 95\% methanol was used as a blank. Extracted prodigiosin was estimated using the following equation (Mekhael and Yousif, 2009).

$$
\begin{gathered}
\text { Prodigiosin unit/cell }=([\mathrm{OD} 499-(1.381 \times \text { OD } \\
620)]) \times 1000 / \text { OD620 }
\end{gathered}
$$

Where:

OD 499-pigment absorbance, OD 620-bacterial cell absorbance, 1.381 - constant

\section{Prodigiosin Bioassay}

\section{Antibacterial activity of prodigiosin}

Disc-diffusion assay on Mueller Hinton Agar (MHA) was used to determine the prodigiosin antibacterial activity against 4 types of $\mathrm{G}^{+}$ bacteria (Staphylococcus aureus, Listeria monocytogenes, Enterococcus faecium and Bacillus cerues) and 7 types of $\mathrm{G}^{-}$bacteria (Salmonella enterides, Proteus vulgaris, Pseudomonas aeruginosa, klebsiella pneumoniae, Aeromonas hydrophila, E. coli and E.coli $\mathrm{O} 157: \mathrm{H7}$ ) as described by Ivanova et al. (2000). These bacteria were obtained from the Agric. Microbiology Dept. Fac. Agric., Zagazig Univ. The pure cultures of the tested indicstors were sub-cultured in Mueller Hinton broth (MHB) and incubated at $37^{\circ} \mathrm{C}$ on a rotary shaker at $200 \mathrm{rpm}$ for $24 \mathrm{hr}$. Each culture was spread uniformly onto individual Mueller Hinton Agar (MHA) plates using spread plate method. $6 \mathrm{~mm}$ diameter sterile filter paper discs were impregnated individually with $50 \mu 1$ of methanolic extract of prodigiosin concentrations $\left(25,50,100,200\right.$ and $\left.400 \mu \mathrm{g} \mathrm{ml}^{-1}\right)$. All the discs were dried and placed on the surface of the tested pathogenic bacteria plates. After incubation at $37^{\circ} \mathrm{C}$ for $24 \mathrm{hr}$., the different resulting inhibition zones diameter were measured (in $\mathrm{mm}$ ). Treatments using 95\% methanol were considered as a control.

\section{Minimum inhibition concentration of prodigiosn (MIC)}

Minimum inhibition concentration (MIC) which identified as the lowest concentration of the test compound which inhibits the visible growth and $\mathrm{IC}_{50}$ (the concentration inducing $50 \%$ inhibition of the bacterial growth) of prodigiosin were determined against the mentioned bacteria using the conventional broth dilution assay (Murray et al., 1995). Serial dilutions of the tested prodigiosin were adjusted to final concentrations of $25,50,100,200$ and $400 \mu \mathrm{g} \mathrm{ml}^{-1}$ of Mueller-Hinton broth (MHB) and $5 \mathrm{ml}$ of each dilution was transferred into $10 \mathrm{ml}$ test tube. To each tube, $100 \mu \mathrm{l}$ of the bacterial inoculum was added and incubated for $24 \mathrm{hr}$., at $37^{\circ} \mathrm{C}$. The turbidity (visible growth) was determined at $600 \mathrm{~nm}$ using JENWAY England 6405 UV/VIS Spectrophotometer after $24 \mathrm{hr}$. At the end of the incubation time, MIC was visually identified and the $\mathrm{IC}_{50}$ was mathematically concluded from the obtained data. All tests were performed in triplicate. Tests using sterilized distilled water were used as negative control. 


\section{Antioxidant activity of prodigiosn}

The extracted pigment was dissolved with 95\% methanol to prepare the stock solution $(2000 \mu \mathrm{g} / \mathrm{ml})$. The tested samples were prepared from stock solution by diluting with methanol to a desired concentration of 1000,400, 200, 100, 50 and $25 \mu \mathrm{g} / \mathrm{ml}$, respectively. Diluted tested samples $(1 \mathrm{ml})$ were added to $1 \mathrm{ml}$ of a $0.004 \%$ methanol solution of DPPH and mixed. After 30 min incubation in the dark, the decrease in absorbance was measured at $517 \mathrm{~nm}$ using spectrophotometer. Ascorbic acid was used as a standard (Renukadevi and Vineeth, 2017). The optical density was recorded and inhibition (\%) was calculated according to the formula:

Inhibition of DPPH activity $(\%)=$

$\left(\mathrm{ABS}_{\text {control }}-\mathrm{ABS}_{\text {sample }}\right) / \mathrm{ABS}$ control $\mathrm{x} 100$

\section{RESULTS AND DISCUSSION}

\section{Identification of the Selected $S$. marcescens}

Thirty two soil samples were collected from Sharkia Governorate, Egypt and screened for red pigment (Prodigiosin) producing organisms. Among the 32 soil samples, Only 13 bacterial isolates which showed clear red pigmented colonies were recovered, purified and slanted. The isolated colonies were identified based on their Phenotypic characteristics and using MALDI-TOF-MS. (matrix-assisted laser desorption ionization-time of flight mass spectrometry). The isolates were confirmed as Serratia marcescens.

\section{Phenotypic Characterization}

Morphological and biochemical characteristics were used to identify the 13 selected bacterial isolates as described by Grimont and Grimont (2005). Results in Table 1 show that all thirteen bacterial isolates were Gram negative, motile, catalase positive, non-produced of Indole, Voges - proskauer test positive, non-production $\mathrm{H}_{2} \mathrm{~S}$, grow in $3 \%$ of $\mathrm{NaCl}$ and non-spore forming bacteria. Also, most the tested isolates can use the citrate as one source for carbon except two isolates ( $\mathrm{Z} 3$ and $\mathrm{S} 1$ ), most of isolates can grow in $7 \%$ of $\mathrm{NaCl}$ except $\mathrm{B} 1, \mathrm{~B} 2, \mathrm{~F} 2$ and $\mathrm{AK}$ isolates. Identifying Serratia marcescens isolates was made mainly on the results of 11 carbohydrate fermentation tests.

\section{Direct Identification of some Tested Bacteroial Isolates using MALDI-TOF-MS}

The selected isolates were identified at Academic Park Fac. Medicine Alex. Univ., Egypt, using MALDI-TOF-MS. Using this advanced method, this identification process was considered as accurate approach to bacterial isolates identification and the prospective strains were identical with their numbers as conserved in the International Cultural Center for Microorganisms (ICCM). The score values for the bacterial isolates are shown in Table 2. All of the isolates showed a score value between 2.565 to $2.668(100 \%)$ and were correctly identified to genus and species levels. Two tested bacterial isolates were type strains that are included in the Bruker Database, and all spectrum scores were greater than 2.0. Thus, all of the tested isolates were correctly identified to genus and species levels with biotype software score values (Bizzini et al., 2010; Wang et al., 2013) greater than 2.0 , and all of them had high degree of precision.

\section{Screening and Determination of Prodigiosin Produced by $\boldsymbol{S}$. marcescens Isolates}

Colorimetric estimations of the prodigiosin pigment in bacterial cultures of Serratia marcescens isolates are shown in Table 3. The highest value of prodigiosin recorded in culture was obtained by M1 isolate (830.2 unit/cell) followed by $\mathrm{S} 1$ isolate (635.5 unit/cell) after 72 hr., of incubation, and the calculated average daily and hourly rates production in the case of M1 isolate and S1 isolate were found to be $421.6,17.5,326.1$ and 13.5 unit/cell, respectively. The lowest value of prodigiosin recorded in culture was obtained by B2 isolate (211.8 U/cell) followed by D1 isolate (215.8.5 unit/ cell) after $48 \mathrm{hr}$., of incubation. Generally, highly amount of prodigiosin obtained after $72 \mathrm{hr}$., of incubation. These results are in agreement with previous results reported by Kamble and Hiwarale (2012). They found that the prodigiosin production is increasing gradually after $48 \mathrm{hr}$., and were maximum towards $72 \mathrm{hr}$., thereafter the production was decreasing towards $92 \mathrm{hr}$., in nutrient broth and peptone glycerol broth. 
Table 1. Biochemical characteristics of $S$. marcescens bacteria isolated from soil samples from Sharkia Governorate

\begin{tabular}{|c|c|c|c|c|c|c|c|c|c|c|c|c|c|}
\hline \multirow[t]{2}{*}{ Characteristic } & \multicolumn{13}{|c|}{ Bacteria isolate } \\
\hline & $\mathbf{Z 1}$ & $\mathbf{Z 2}$ & $\overline{Z 3}$ & $\overline{\text { B1 }}$ & B2 & MS & F1 & F2 & S1 & H1 & M1 & M2 & $\overline{\mathrm{AK}}$ \\
\hline Gram reaction & - & - & - & - & - & - & - & - & - & - & - & - & - \\
\hline Motility & + & + & + & + & + & + & + & + & + & + & + & + & + \\
\hline Catalase & + & + & + & + & + & + & + & + & + & + & + & + & + \\
\hline Indole & - & - & - & - & - & - & - & - & - & - & - & - & - \\
\hline Voges - Proskauer & + & + & + & + & + & + & + & + & + & + & + & + & + \\
\hline Citrate & + & + & - & + & + & + & + & + & - & + & + & + & + \\
\hline $\mathrm{H}_{2} \mathrm{~S}$ production & - & - & - & - & - & - & - & - & - & - & - & - & - \\
\hline Lipase production & - & + & + & + & + & - & + & + & + & + & + & + & + \\
\hline Growth in $\mathrm{NaCl} \mathrm{3 \%}$ & + & + & + & + & + & + & + & + & + & + & + & + & + \\
\hline Growth in $\mathrm{NaCl} 7 \%$ & + & + & + & - & - & + & + & - & + & + & + & + & - \\
\hline Lactose & - & - & - & - & - & - & - & - & - & + & - & - & - \\
\hline Glucose & + & + & + & + & + & + & + & + & + & + & + & + & + \\
\hline Mannitol & + & + & + & + & + & + & + & + & + & + & + & + & + \\
\hline Cellobiose & - & - & - & - & - & - & - & - & - & - & - & - & - \\
\hline Raffinose & - & - & - & - & - & - & - & - & - & - & - & - & - \\
\hline Rhamnose & - & - & - & - & - & - & - & - & - & - & - & - & - \\
\hline Sorbitol & + & + & + & + & + & + & + & + & + & + & + & + & + \\
\hline Fructose & - & + & + & + & + & + & + & + & + & + & + & + & + \\
\hline Maltose & + & + & + & + & + & + & + & + & + & + & + & + & + \\
\hline Ribose & + & + & + & + & + & + & + & + & + & + & + & + & + \\
\hline Sucrose & + & + & + & + & + & + & + & + & + & + & + & + & + \\
\hline
\end{tabular}

Table 2. Rate of classification results as determined by Bruker Daltonik MALDI Biotyper

\begin{tabular}{cccc}
\hline Isolate code & Analyte name & Organism(best match) & Score value \\
\hline M1 & B17 (+++) (A) & Serratia marcescens ssp marcescens DSM 30121T DSM & 2.565 \\
S1 & B15 (+++) (A) & Serratia marcescens DSM 30122 DSM & 2.668 \\
\hline
\end{tabular}


Table 3. Changes in amounts of prodigiosin (unit/cell) produced by different $S$. marcescens isolates as affected by incubation time

\begin{tabular}{cccccc}
\hline Serratia isolate & \multicolumn{5}{c}{ Prodigiosin (unit/cell) } \\
\cline { 2 - 6 } & $\mathbf{4 8} \mathbf{~ h r}$. & $\mathbf{7 2} \mathbf{~ h r}$. & $\mathbf{9 6} \mathbf{~ h r}$. & $\begin{array}{c}\text { Average daily rate } \\
\text { production }\end{array}$ & $\begin{array}{c}\text { Average hourly } \\
\text { rate production }\end{array}$ \\
\hline MS & 272.6 & 457.4 & 348.7 & 269.6 & 11.2 \\
AK & 357.9 & 506.4 & 434.1 & 324.6 & 13.5 \\
B1 & 257.2 & 341.9 & 234.9 & 208.5 & 8.6 \\
B2 & 211.8 & 467.2 & 392.9 & 267.9 & 11.1 \\
M1 & 552.8 & 830.2 & 303.4 & 421.6 & 17.5 \\
M2 & 251.6 & 430.3 & 280.5 & 240.6 & 10.0 \\
H1 & 215.8 & 448.9 & 426.0 & 272.6 & 11.3 \\
S1 & 336.9 & 635.5 & 332.0 & 326.1 & 13.5 \\
Z1 & 289.4 & 487.4 & 309.7 & 271.6 & 11.3 \\
Z2 & 301.4 & 450.7 & 353.3 & 276.3 & 11.5 \\
Z3 & 404.2 & 586.0 & 361.7 & 337.9 & 14.0 \\
F1 & 387.0 & 453.7 & 395.0 & 308.9 & 12.8 \\
F2 & 416.7 & 504.2 & 297.4 & 304.5 & 12.6 \\
\hline
\end{tabular}

\section{Antibacterial Activity of Prodigiosin}

Prodigiosin extracted from Egyptian Serratia marcescens strains were used to study their action as antibacterial agent against $4 \mathrm{G}^{+}$bacteria (S. aureus, L. monocytogenes, E. faecium and $B$. cerues) and $7 \mathrm{G}^{-}$bacteria ( $S$. enterides, $P$. vulgaris, $P$. aeruginosa, $K$. pneumonia, A. hydrophila, E. coli and E. coli $\mathrm{O} 157$ : $\mathrm{H} 7)$.

Disc diffusion assay was performed in this respect. The antibacterial activity of different concentrations of prodigiosin $(25,50,100,200$ and $400 \mu \mathrm{g} / \mathrm{ml}$ ) was assayed against all the aforementioned pathogenic tested indicators by measuring the area of the inhibition zones after incubation at $37^{\circ} \mathrm{C}$ for $24 \mathrm{hr}$. Results in Table 4 show that the growth of all aforementioned bacteria was inhibited by all concentrations of prodigiosin used in this experiment. Furthermore, the diameter of the inhibition zones increased proportionally with the increase of prodigiosin concentrations. The clear zone diameter in all tested bacteria ranged between 7 to $29 \mathrm{~mm}$ under different prodigiosin concentrations. The highest inhibition zone was obtained in the case of $K$. pnuemonia $(29 \mathrm{~mm})$ at a concentration of $400 \mu \mathrm{g} / \mathrm{ml}$ of prodigiosin. The inhibitory action of prodigiosin against the $\mathrm{G}^{-}$bacteria (especially $S$. enterides and $K$. pnuemonia) was always higher than that of all tested bacteria. The prodigiosin has an antibacterial, antiprotozoal, antitumor and antiinflammatory activity (PerezTomas and Vinas 2010). It has been demonstrated that prodigiosin inhibits growth of a wide spectrum of Gram positive bacteria (B. subtilis and $S$. Aureus) as well as Gram negative (E. coli, $S$. enterica and Erwinia carotovora) (Danevčič et al., 2016). The antimicrobial study of prodigiosin revealed that it is a potent inhibitor of $\mathrm{G}^{+}$bacteria as well as $\mathrm{G}^{-}$bacteria (Chauhan et al., 2017). 
Table 4. Disc diffusion assay of the antibacterial action of prodigiosin $(25-400 \mu \mathrm{g} / \mathrm{ml})$ against 4 $\mathbf{G}^{+}$and $7 \mathbf{G}^{-}$bacteria

\begin{tabular}{|c|c|c|c|c|c|c|c|c|c|c|c|}
\hline \multirow{3}{*}{$\begin{array}{c}\text { Concentrations of } \\
\text { prodigiosin }\end{array}$} & \multicolumn{11}{|c|}{ Inhibition of bacterial growth (mm) } \\
\hline & \multicolumn{4}{|c|}{ Gram positive bacteria } & \multicolumn{7}{|c|}{ Gram negative bacteria } \\
\hline & 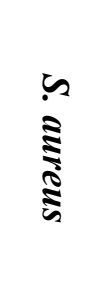 & 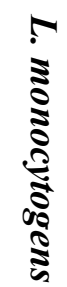 & 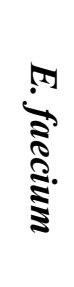 & 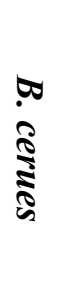 & 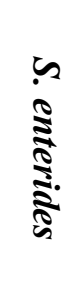 & 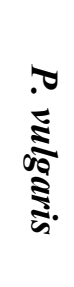 & 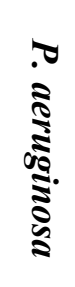 & 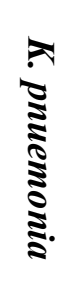 & 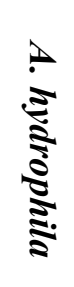 & 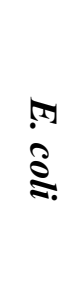 & 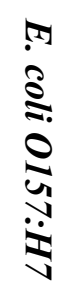 \\
\hline $25 \mu \mathrm{g} / \mathrm{ml}$ & 8 & 8 & 9 & 10 & 13 & 9 & 7 & 15 & 9 & 9 & 9 \\
\hline $50 \mu \mathrm{g} / \mathrm{ml}$ & 8 & 10 & 10 & 10 & 15 & 12 & 10 & 18 & 10 & 10 & 11 \\
\hline $100 \mu \mathrm{g} / \mathrm{ml}$ & 9 & 11 & 10 & 11 & 17 & 14 & 12 & 22 & 13 & 10 & 11 \\
\hline $200 \mu \mathrm{g} / \mathrm{ml}$ & 10 & 11 & 10 & 12 & 20 & 14 & 18 & 26 & 13 & 11 & 12 \\
\hline $400 \mu \mathrm{g} / \mathrm{ml}$ & 10 & 12 & 11 & 14 & 24 & 17 & 20 & 29 & 15 & 12 & 12 \\
\hline
\end{tabular}

\section{Minimum Inhibition Concentration of Prodigiosin (MIC)}

Antibacterial inhibiting action of different concentrations of Serratia prodigiosin was assayed as described by Murray et al. (1995). Results in Table 5 show that the antibacterial action was observed when adding prodigiosin at different concentrations $(25-400 \mu \mathrm{g} / \mathrm{ml})$ to the aforementioned bacteria $\left(4 \mathrm{G}^{+}\right.$bacteria and $7 \mathrm{G}^{-}$ bacteria) inoculated in MHB tubes and incubated at $37^{\circ} \mathrm{C}$ for $24 \mathrm{hr}$. Prodigiosin concentration corresponding to $50 \%$ inhibition of $\mathrm{G}^{+}$bacteria $\left(\mathrm{IC}_{50}\right)$ was in the range of 26.18 to $51.54 \mu \mathrm{g} / \mathrm{ml}$ of prodigiosin and 20.31 to $69.71 \mu \mathrm{g} / \mathrm{ml}$ of prodigiosin for $\mathrm{G}^{-}$bacteria. Red pigment prodigiosin whish produced by Serratia marcescens showed intracellular antibacterial action higher susceptibility against Gram positive than Gram negative bacteria. The same characteristics were observed in other antimicrobial studies on plant and cyanobaterial extracts against pathogenic bacteria (Tong et al., 2014; Sitohy et al., 2015).

\section{Antioxidant Activity of Serratia prodigiosin}

Changes in DPPH radical scavenging activity (RSA) of prodigiosin at different concentrations $(25,50,100,200,400,1000 \mu \mathrm{g} / \mathrm{ml})$ are presented in Table 6. It can be noted that, the antioxidant activity of prodigiosin increased gradually with increasing concentration. At different concentrations, the extracted Serratia prodigiosin was tested for the radical scavenging effect against DPPH. The DPPH free radicals scavenging activity of prodigiosin were found to be $51.79,59.82,60.49,62.05,63.17$ and $92.63 \%$ at $25,50,100,200,400$ and $1000 \mu \mathrm{g} / \mathrm{ml}$ of Serratia prodigiosin, respectively. Total antioxidant capacity was reported as ascorbic acid equivalents (Renukadevi and Vineeth, 2017). The result indicates that the antioxidant activity of prodigiosin is lower than that of standard ascorbic acid. 
Table 5. Minimum inhibition concentration (MIC) and $\mathrm{IC}_{50}$ of prodigiosin $(25-400 \mu \mathrm{g} / \mathrm{ml})$ against $4 \mathbf{G}^{+}$and $7 \mathbf{G}^{-}$bacteria

\begin{tabular}{|c|c|c|c|c|c|c|c|c|c|c|c|}
\hline \multirow{3}{*}{$\begin{array}{c}\text { Concentrations of } \\
\text { prodigiosin }\end{array}$} & \multicolumn{11}{|c|}{ Inhibition of bacterial growth (OD) } \\
\hline & \multicolumn{4}{|c|}{ Gram positive bacteria } & \multicolumn{7}{|c|}{ Gram negative bacteria } \\
\hline & 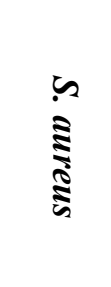 & 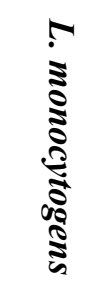 & 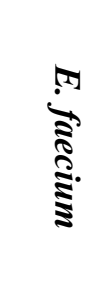 & 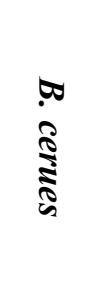 & 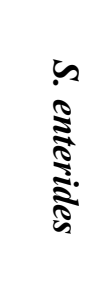 & 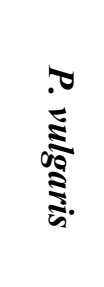 & 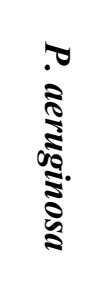 & 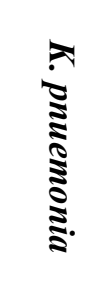 & 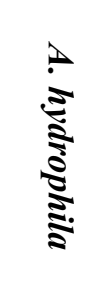 & $\begin{array}{l}\pi \\
\vdots \\
\vdots\end{array}$ & 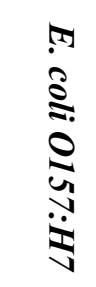 \\
\hline $00 \mu \mathrm{g} / \mathrm{ml}$ (control) & 1.15 & 1.34 & 0.94 & 0.76 & 1.39 & 1.28 & 1.61 & 1.34 & 1.19 & 1.25 & 1.15 \\
\hline $25 \mu \mathrm{g} / \mathrm{ml}$ & 0.95 & 0.92 & 0.61 & 0.33 & 0.94 & 0.67 & 1.45 & 0.74 & 0.95 & 0.61 & 0.53 \\
\hline $50 \mu \mathrm{g} / \mathrm{ml}$ & 0.51 & 0.65 & 0.27 & 0.26 & 0.80 & 0.63 & 1.33 & 0.69 & 0.90 & 0.56 & 0.10 \\
\hline $100 \mu \mathrm{g} / \mathrm{ml}$ & 0.16 & 0.18 & 0.16 & 0.20 & 0.12 & 0.11 & 1.29 & 0.14 & 0.24 & 0.14 & 0.09 \\
\hline $200 \mu \mathrm{g} / \mathrm{ml}$ & 0.08 & 0.09 & 0.05 & 0.07 & 0.03 & 0.03 & 0.38 & 0.10 & 0.16 & 0.10 & 0.01 \\
\hline $400 \mu \mathrm{g} / \mathrm{ml}$ & 0.00 & 0.00 & 0.00 & 0.00 & 0.00 & 0.00 & 0.00 & 0.00 & 0.00 & 0.00 & 0.00 \\
\hline $\mathrm{IC}_{50}(\mu \mathrm{g} / \mathrm{ml}$ of prodigiosin $)$ & 51.17 & 51.54 & 26.18 & 33.61 & 56.56 & 50.81 & 69.71 & 48.63 & 66.98 & 44.20 & 20.31 \\
\hline
\end{tabular}

Table 6. Antioxidant activity of prodigiosin

\begin{tabular}{lcc}
\hline Concentrations & Prodigiosin SA & Ascorbic methanol SA \\
\hline $\mathbf{2 5} \boldsymbol{\mu g} / \mathbf{m l}$ & 51.79 & 98.66 \\
$\mathbf{5 0} \boldsymbol{\mu} \mathbf{g} / \mathbf{m l}$ & 59.82 & 99.33 \\
$\mathbf{1 0 0} \boldsymbol{\mu} \mathbf{g} / \mathbf{m l}$ & 60.49 & 99.55 \\
$\mathbf{2 0 0} \boldsymbol{\mu} \mathbf{g} / \mathbf{m l}$ & 62.05 & 99.55 \\
$\mathbf{4 0 0} \boldsymbol{\mu \mathbf { g } / \mathbf { m l }}$ & 63.17 & 101.56 \\
$\mathbf{1 0 0 0} \boldsymbol{\mu} \mathbf{g} / \mathbf{m l}$ & 92.63 & 108.93 \\
\hline
\end{tabular}

\section{REFERENCES}

Alihosseini, F., J.U.K.S.J. Lango, B.D. Hammock and G. Sun (2008). Antibacterial colorants: Characterization of prodiginines and their applications on textile materials. Biotechnol Progr., 24 (3): 742-7.

Araújo, H.W.C., K. Fukushima and G.M.C. Takaki (2010). Prodigiosin production by Serratia marcescens UCP 1549 using renewable-resources as a low cost substrate. Molecules, 15- 6931-6940.

Biswass, S. and J.M. Rolain (2013). Use of MALDI-TOF mass spectrometry for identification of bacteria that are difficult to culture. J. Microbiol. Meth., 92:14-24.

Bizzini, A., C. Durussel, J. Bille, G. Greub and G. Prod'hom (2010). Performance of matrixassisted laser desorption ionization-time of flight mass spectrometry for identification of 
bacterial strains routinely isolated in a clinical microbiology laboratory. J. Clin. Microbiol., 48 : 1549-1554.

Bizzini, A., K. Jaton, D. Romo, J. Bille, G. Prod'hom and G. Greub (2011). Matrixassisted laser desorption ionization-time of flight mass spectrometry as an alternative to 16S rRNA gene sequencing for identification of difficult-to-identify bacterial strains. J. Clin. Microbiol., 49:693-6. 4.

Chauhan, R., A. Choudhuri and J. Abraham (2017). Evaluation of antimicrobial, cytotoxicity, and dyeing properties of prodigiosin produced by Serratia marcescens strain jar8. Asian J. Pharm. Clin. Res., 10 (8): 279-283.

Danevčič, T., M. Borić Vezjak, M. Tabor, M. Zorec and D. Stopar (2016). Prodigiosin induces autolysins in actively grown Bacillus subtilis cells. Front Microbiol., 7: 27.

Gerber, N.N. and M.P. Lechevalier (1976). Prodiginine (prodigiosin-like) pigments from Streptomyces and other Actinomyces. Canadian J. Microbiol., 22: 658-667.

Grimont, F. and P.A.D. Grimont (2005). Seen in Bergey's Manual of Systematic Bacteriology, $2^{\text {nd }}$ Ed., (The Proteobacteria) Part B, The Gamma Proteobacteria, Springer, XXXIV, 799: 811.

Gulani, C., S. Bhattacharya and A. Das (2012). Assessment of process parameters influencing the enhanced production of prodigiosin from Serratia marcescens and evaluation of its antimicrobial, antioxidant and dyeing potentials. Malaysian J. Microbiol., 8 (2): 116-122.

Hardjito, L., A. Huq and R. R. Colwell (2002). The influence of environmental conditions on the production of pigment by Serratia marcescens, Biotechnol. Bioprocess Eng., 7: $100-104$.

Iranshahi, M., A.R. Shahverdi, R. Mirjani, G. Amin and A. Shafiee (2004). Umbelliprenin from Ferula persica Roots Inhibits the Red Pigment Production in Serratia marcescens. Verlag der Zeitschrift für Naturforschung, Tübingen., 506-508.
Ivanova, I., P. Kabadjova, A. Pantev, S. Danova and X. Dousset (2000). Detection, purification and partial characterization of a novel bacteriocin substance produced by Lactoccous lactis subsp. lactis b14 isolated from Boza-Bulgarian traditional cereal beverage. Biocatalysis, 41(6): 47-53.

Kamble, K.D. and V.D. Hiwarale (2012). Prodigiosin production from Serratia marcescens strains obtained from farm soil. Int. j. Environ. Sci., 3 (1): 631-638.

Mekhael, R. and S.Y. Yousif (2009). The role of red pigment produced by Serratia marcescens as antibacterial and plasmid curing agent. J. of Duhok University 12: 268274.

Murray, P.R., E.J. Baron, M.A. Pfallar, F.C. Tenover and R.H. Yolke (1995). $6^{\text {th }}$ Ed. Manual of Clinical Microbiology, ASM, Wash-ington DC, 6: 214-215.

Nacef, M., M. Chevalier, S. Chollet, D. Drider and C. Flahaut (2016). MALDI-TOF mass spectrometry for the identification of lactic acid bacteria isolated from a French cheese: The Maroilles. Int. J. Food Microbiol., 1-7.

Perez-Tomas, R. and M. Vinas (2010). New insights on the antitumoral properties of prodiginines. Curr. Med. Chem., 17: 21: 2222-2231.

Phatake, Y.B. and S. Dharmadhikari (2016). Evaluation of cytotoxic and anticancer activity of prodigiosin produced by Serratia Spp. Ame. J. Pharm. Tech. Res., 6 (3)- 720 736.

Renukadevi, K.P. and M. Vineeth (2017). Antimicrobial, antioxidant and cytotoxicity activity of pigment produced from serratia marcescens. Euro. J. Biomed. Pharmac. Sci., 4 (2): 265-269.

Samrot, A.V., K. Chandana, P. Senthilkumar and N. Kumar (2011). Optimization of prodigiosin production by Serratia marcescens SU-10 and evaluation of its bioactivity. Int. Res. J. Biotechnol., 2 (5): 128-133.

Sitohy, M., A. Osman, A.G.A. Ghany, A. Salama (2015). Antibacterial phycocyanin 
from Anabaena oryzae SOS13. Int. J. Appl. Res. in Nat. Prod., 8 : 27-36.

Someya, N., M. Nakajima, K. Watanabe, T. Hibi and K. Akutsu (2003). Influence of bacteria isolated from rice plants and rhizospheres on antibiotic production by the antagonistic bacterium Serratia marcescens strain B2. J. Gen. Plant Pathol., 69 (5): 342-347.

Songia, S., A. Mortellaro, S. Taverna, C. Fornasiero, E.A. Scheiber, E. Erba, F. Colotta, A. Mantovani, A. M. Isetta and J. Golay (1997). Characterization of the new immunosuppressive drug undecylprodigiosin in human lymphocytes: Retinoblastoma protein, cyclin-dependent kinase-2, and cyclin-dependent kinase-4 as molecular targets. J. Immunol., 158 (8): 3987-95.

Su, W.T., T.Y. Tsou and H.L. Liu (2011). Response surface optimization of microbial prodigiosin production from Serratia marcescens. J. Taiwan Inst. Chem. Eng., 42 (2): 217-22.

Tadros, M. and A. Petrich (2013). Evaluation of MALDI-TOF mass spectrometry and Sepsityper KitTM for the direct identification of organisms from sterile body fluids in a
Canadian pediatric hospital. Can. J. Infect. Dis. Med. Microbiol., 24: 191-4.

Tong, W.Y., J. Nurul-Zaadah, W.N.T. Nurhaida, K. Melati, Z. Latiffah and I. Darah (2014). Antimicrobial activity of Phomopsis sp. ED2 residing in medicinal plant Orthosiphon stamineus Benth. Ann. Res. Rev. Biol., 4 (9): 1490-1501.

Wang, Y.R., Q. Chen, C.S. Hui and L.F. Qin (2013). Characterization of Staphylococcus aureus isolated from clinical specimens by matrix assisted laser desorption/ionization time-off light mass spectrometry. Biomed. Environ. Sci., 26 (6): 430-436.

Wei, Y.H., W.J. Yu and W.C. Chen (2005). Enhanced undecylprodigiosin production from Serratia marcescens SS-1 by medium formulation and amino-acid supplementation. J. Biosci. Bioeng., 100 (4): 466-471.

Yonetani, S., H. Ohnishi, K. Ohkusu, T. Matsumoto and T. Watanabe (2016). Direct identification of microorganisms from positive blood cultures by MALDI-TOF MS using an in-house saponin method. Int. J. Infect. Dis., 52: 37-42.

\section{عزل وتعريف سلالات مصرية من الـ سيراتيا مارسيسنس المنتجة لصبغة البروديجيوزين المضادة للبكتريا ومضادة للأكسدة}

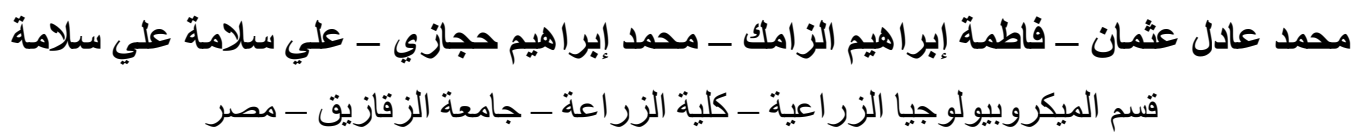

تم عزل وتنقية سا 1 عزلة من بكتريا الـ Serratia marcescens التابعة لعائلة الـ Enterobacteriaceae و المنتجة

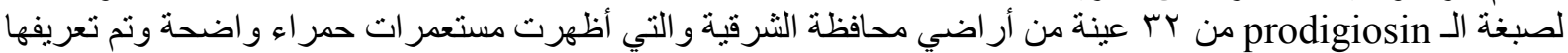

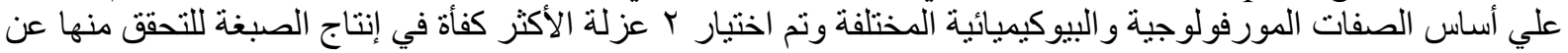

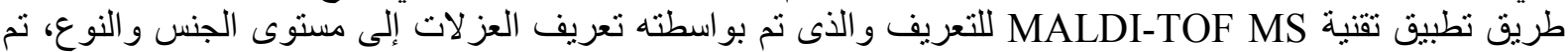

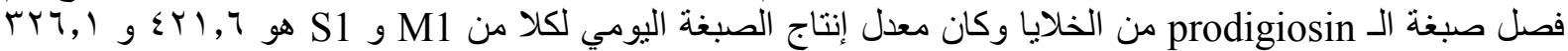

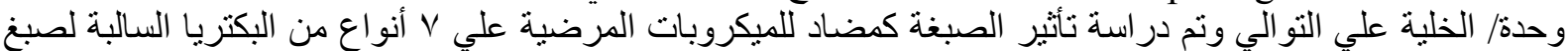

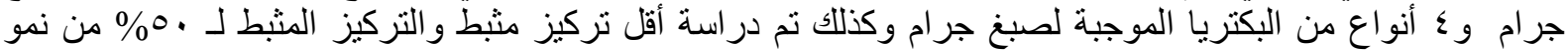

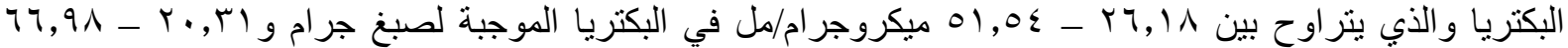

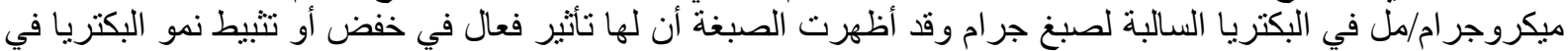

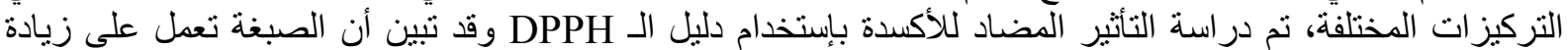
النشاط المضاد للأكسدة بزيادة التركيز.

\footnotetext{
أستاذ الميكروبيولوجيا ـ كلية العلوم - جامعة بنها. أستاذ الميكروبيولوجيا الزر اعية المتفرغ ـ ـلية الزر اعة - جامعة الزقازيق.
}

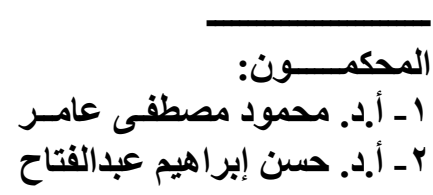

